\title{
Evaluation of Rainwater Harvesting System with Shared Built Tank in Housing Development in Tropical Climate
}

\author{
Rawia Marwan Dabdoob \\ Department of Architecture \\ Mosul University \\ Mosul, Iraq
}

\author{
Puterishireen Jahn Kassim \\ Department of Architecture \\ International Islamic University Malaysia \\ Malaysia
}

\begin{abstract}
The research aims to firstly, investigate the discrepancy between estimated performance and actual performance after occupancy; and secondly, to estimate the lifecycle saving of the rainwater harvesting system lifetime duration. The research focuses on Mesra Terrace Development in Kuala Lumpur as a case study. The study employed a quantitative method for the data collection. The empirical assessment of the after occupancy performance is based on the analysis of water consumptions and savings in both designed and operational phases. The findings indicate that the Rainwater harvesting system has met water efficiency target but did not meet the life-cycle savings target.
\end{abstract}

Keywords - Green technologies, Post occupancy performance, Occupants behavior, Lifecycle saving

\section{INTRODUCTION}

Harvesting rainwater from house's roof areas and use it for some purposes in residential parts such as irrigation or washing vehicles is considered sustainable approach to save portable water that been consumed for the same needs [1]. Promoting rainwater harvesting improves water efficiency and cost saving by reducing the potential of water treatment, supply and delivery from the main water grid, besides, conserving drainage systems [2][3]. As the climate of Malaysia is equatorial, there is abundant tropical rainfall during all seasons [4]. Thus, rainwater harvesting system represents a significant strategy in green homes in Malaysia. Rainwater harvesting program was launched in Malaysia by government since more than two decades aiming to reduce over dependence on river water [2]. However, and likewise any green technology, some results of simulation models and calculations of rainwater harvesting system, may not meet actual performance after occupancy [5]. Besides, in residential homes, it is very hard to predict occupants' behavior, and hence, patterns of water usage [6].

This paper aims to investigate the discrepancy between estimated performance and actual performance; and to estimate the lifecycle saving of the rainwater harvesting system lifetime duration. Mesra Terrace Development in Kuala Lumpur is selected as a case study where a central large storage tank was built in the central courtyard of the development as part of common rainwater harvesting system.

\section{LITERATURE REVIEW}

The rainfall is collected usually from house's roof areas of and it is stored in water butt, or storage tanks after removing contaminants by filtration [4][7]. The collected water is reused in non-potable domestic demands such as irrigating garden, flushing toilets, and outdoor cleaning [2][7]. Noticeably, in sustainable housing, rainwater harvesting system is either designed individually in each dwelling, or shared by large tank to serve many or all dwellings.

Current challenges in improving domestic water efficiency have led many countries to develop strategic policies in addressing new residential buildings to be designed to perform the ultimate performance. Hence, in compliance with climates, as well as social and economic requirements, many international green homes and sustainable housing developments have been constructed with effective rainwater harvesting systems[7][8]. Selected sustainable medium and low housing developments in the UK implemented different strategies in water storage, as indicated in TABLE 1.

TABLE 1. Rainwater harvesting systems in selected sustainable housing developments in the UK

\begin{tabular}{|c|c|c|}
\hline $\begin{array}{c}\text { Housing Development Name } \\
\begin{array}{c}\text { Freshney Green Development: } \\
\text { in Grimsby }\end{array}\end{array}$ & $\begin{array}{c}\text { Water } \\
\text { saving }\end{array}$ \\
$\begin{array}{c}\text { comprises of } 67 \text { dwellings in } \\
\text { different scales }\end{array}$ & $66 \%$ \\
$\begin{array}{c}\text { One Earth Homes: } \\
\text { in Northampton } \\
\text { six terraced net zero carbon } \\
\text { dwellings }\end{array}$ & $100 \%$ & $39 \%$ \\
\hline $\begin{array}{c}\text { BedZED Development: } \\
\text { in Sutton } \\
\text { consists of 6 plots of } \\
\text { block comprises } 18 \text { units }\end{array}$ &
\end{tabular}

Particularly, in Freshney Green Development, rainwater is harvested from each dwelling's roof by individual water butts and used in irrigation. The system contributes in saving $66 \%$ of external water usage. In One Earth Homes, rainwater is harvested from the roof of each home and collected in storage 
under the ground. Later, this water is pumped into a tank in the attic to be reused as non-potable water in flushing the toilet [9]. The collected water achieved $100 \%$ of water saving for this purpose. In BedZED Development, Rainwater is harvested from the southern side of the dwellings' roofs and transferred through pipes supplied with water filter to eliminate the impurities. The clean water is collected in a large cylinder storage tank placed underground along the length of each terrace block. It is worth noting that the treated waste water, called green water, is collected in this large storage with the harvested rainwater. This green water is pumped and reused as non-potable water for toilet flushing in the dwellings. The surplus green water is used in garden irrigation [10]. It was planned to reduce mains water usage in BedZED Development to about 33\% compared to the conventional home in the area Range of efficient appliances were embraced to reduce main water usage, including low flush toilets, washing machines, spray taps, and not powered showers. These efficient appliances facilitate $60 \%$ of water efficiency. However, the green water treatment plant was stopped due to difficulties in maintaining. This has affected water saving by reducing it to $39 \%,[10][11]$.

\section{METHODOLOGY}

\section{A. The Case Study: Mesra Teerace Development}

Mesra Terrace development is a gated low density housing development located at the end of Dutamas Raya street in the arising neighborhood of Dutamas, 51200Kuala Lumpur, Malaysia. The construction of the development was completed in 2009. In conjunction with eco-friendly environment, the site was planned to hold 40 dwellings of peculiar communal community with wide central green courtyard. The site of the development has trapezoidal shape with considerable slope in its topographic. Therefore, the eco concept of planning was to create communal urban with private central courtyard as private landscape garden, as illustrated in "Fig. 1 ".

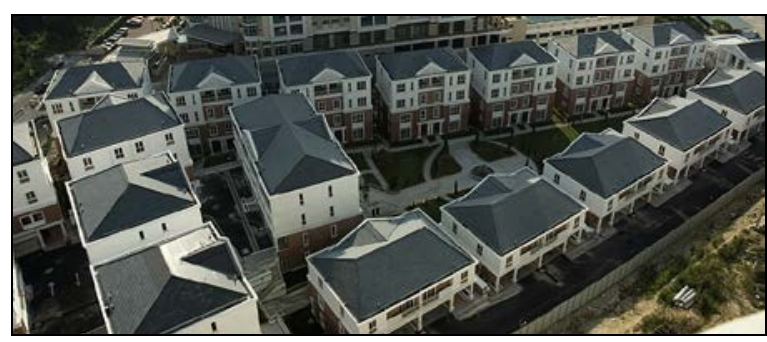

Fig. 1. Mesra Terrace Development

Rainwater harvesting system was constructed as a common tank in the central courtyard of the development to achieve water efficiency for the common and outdoor areas usage. The idea was to exploit the area of the center courtyard to hold a central large storage tank as part of common rainwater harvesting system. The system was designed and instilled with three elements, particularly, collected elements, storage tank, and distribution elements. Firstly, gutters capture the rainwater from each dwelling's roof, which provide area of rainfall harvesting about 6,000m2, and direct it to main two downpipe lines, each of $150 \mathrm{~mm}$ gross radius, as illustrated in "Fig. 2 ".

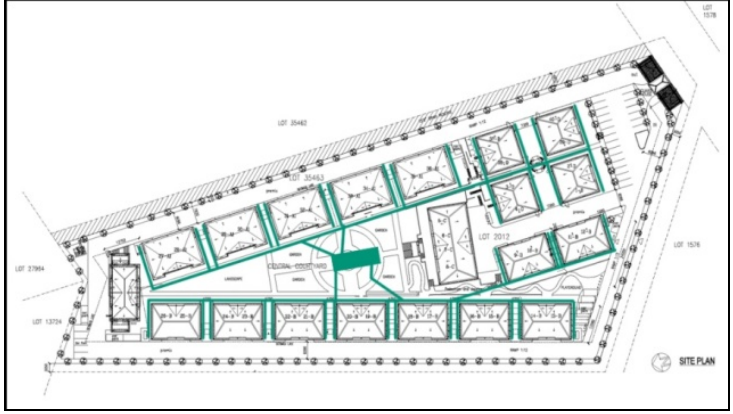

Fig. 2. The collection downpipes system

The downpipes flow the collected rainwater into sump of $600 \mathrm{~mm}$ depth underground, as depicted in "Fig. 3 " in which it goes through filters to clean up from sediments.

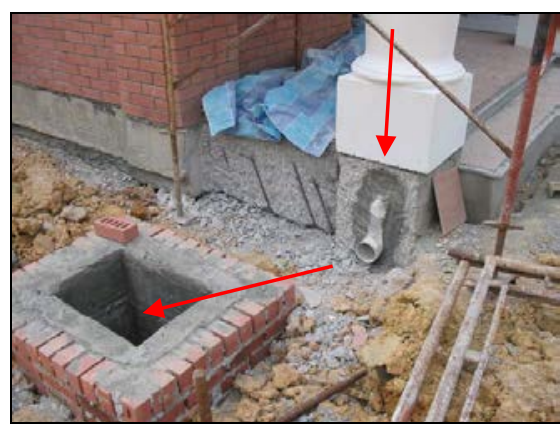

Fig. 3. The collection sump under construction

Then, it is stored in the tank which was excavated and built up in the center landscape under the garden, as depicted in "Fig. 4". The capacity of the storage tank is 55,000 gallon that equals to 208,175 liters.
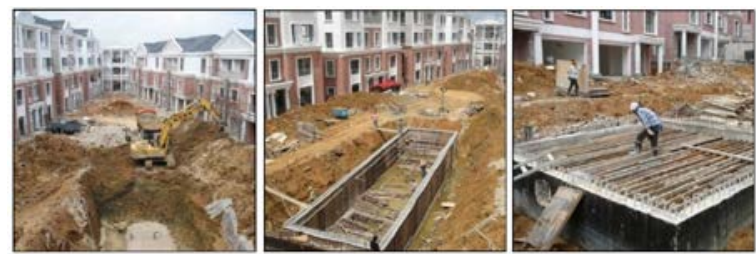

Fig. 4. Excavation, formwork, and casting the storage tank

In order to distribute the water from the tank to the garden and to club house in conforming with saving energy target, one motor pump is used to inject the water up to a small tank placed at the highest point of the land slope of the development site topography to allow the water to flow by the power of earth gravity. This process, as exhibited in “Fig. 5". was applied to ensure energy conservation instead of using at least five motor pumps to feed the demands. Basically, five main piped of 50mm gross radius supply the garden where grass and shrubs are irrigated, feeding two fountains, and the club house, where a service of washing cars is available for occupants, and other outdoor water needs such as cleaning the walkway. This would reflect on water saving and bill reduction of the common area of the development. 

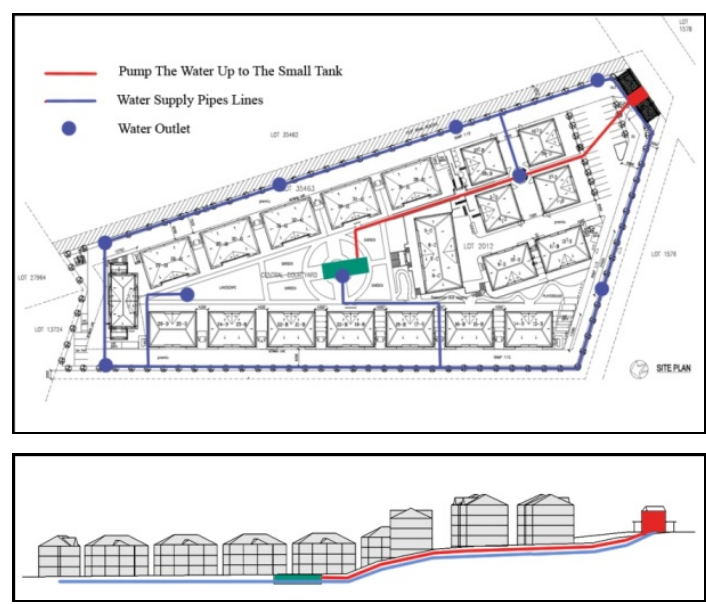

Fig. 5. The construction of the storage tank.

\section{B. Data Collection}

The data addresses rainwater harvesting system performance in correlation with water efficiency and cost savings after commissioned. Hence, data collection includes:

1. Water consumption is collected from water bills for six months from the three water meters in the development.

2. Collected water by water harvesting system in the development. The amount of harvested water was estimated by the Developer through observation during four years.

3. Capital cost of the development and green cost premium of the rainwater harvesting system.

4. Water consumption $\left(\mathrm{m}^{3}\right)$ to Malaysian currency (RM) based on water tariff which is considered 65.00cent per one m3 (1RM is equal to 100 cents).

The technique of collecting data from the local case study, Mesra Terrace Development, was confined to in-depth interview with the Developer of Mersa Terrace Development with duration from 3:45pm to 6:00pm, in Palam Mesra Sdn. Bhd, Desa Sri Hartamas. The in-depth interview was held to complete the quantitative data. Detailed questions was directed to the Developer about performance of rainwater harvesting system in terms of water efficiency and lifecycle saving. Besides, it was oriented to earn the Developer's perception upon the implemented green technologies, and to report the needs and determine their benefits and defects after occupancy.

\section{RESULTS AND DISCUSSION}

\section{A. Estimated Rainwater Volume Collected by the Rainwater Harvesting System}

The Developer stated that rainwater harvesting system was designed according to predicted outdoor water usage demands. The water amount required to irrigate grass and shrubs was calculated. Besides, the water needed to wash walkway, as well as occupants' cars was estimated regarded to frequency of demands. TABLE 2 indicates daily estimated water consumption which is about 31, 395 liters, with an annual amount of 11,459,175 liters.
TABLE 2. Water consumption prediction

\begin{tabular}{|c|c|c|c|c|c|}
\hline $\begin{array}{c}\text { Type of } \\
\text { requirements }\end{array}$ & Area & $\begin{array}{c}\text { Water } \\
\text { needed }\end{array}$ & $\begin{array}{c}\text { Water } \\
\text { needed } \\
\text { (per } \\
\text { day) } \\
\text { (litre) }\end{array}$ & $\begin{array}{c}\text { Frequent } \\
\text { of } \\
\text { demands }\end{array}$ & $\begin{array}{c}\text { Daily water } \\
\text { consumption } \\
\text { (litre) }\end{array}$ \\
\hline $\begin{array}{c}\text { Irrigating } \\
\text { grass and } \\
\text { shrubs }\end{array}$ & $1,650 \mathrm{~m} 2$ & $\begin{array}{c}6.3 \\
1 / \mathrm{m} 2 / \text { day }\end{array}$ & 10,395 & Daily & 10,395 \\
\hline $\begin{array}{c}\text { Cleaning the } \\
\text { walkway }\end{array}$ & $1,600 \mathrm{~m} 2$ & $151 / \mathrm{m} 2$ & 24,000 & $\begin{array}{c}\text { Every } \\
\text { two days }\end{array}$ & 12,000 \\
\hline $\begin{array}{c}\text { Washing } \\
\text { cars }\end{array}$ & 0 0ne car & 30001 & 3000 & $\begin{array}{c}\text { Three } \\
\text { cars } \\
\text { daily }\end{array}$ & 9,000 \\
\hline \multicolumn{2}{|c|}{ Total daily estimated water consumption } & \multicolumn{2}{|c|}{31,395 (litre) } \\
\hline \multicolumn{2}{|c|}{ Monthly estimated water consumption } & \multicolumn{2}{|c|}{$954,931.25$ (litre) } \\
\hline \multicolumn{2}{|c|}{ Annual estimated water consumption } & \multicolumn{2}{c|}{$11,459,175$ (litre) } \\
\hline
\end{tabular}

The area of rainfall collection and the volume of the large storage tank were determined according to the annual rainwater harvesting potential. Since, the rainfall average in Kuala Lumpur has about 2,300mm precipitation [6], the predicted annual collected rainwater in litre (l) is equal to; Annual rainfall averages * area of rainfall collection [10].

$$
2,3001 / \mathrm{m} 2 * 6,000 \mathrm{~m} 2=13,800,000 \text { liters }
$$

However, harvesting efficiency process might be affected by evaporation, or spillage. Therefore, the potential of collecting rainwater is taken as $90 \%$ [12]. Hence, rainwater harvesting potential is equal to;

Annual rainwater harvesting (L) * Collection efficiency $=14,260,000$ liters $* 0.9=12,834,000$ liters annually.

By the above calculation, collected rainwater was estimated at $12,834,000$ liters annually which is convergent with the annual water consumption requirement. This collected rainwater provides annual savings about RM8342100.

\section{B. Trends in Actual Collected Rainwater Volume}

The Developer of Mesra Terrace Development stated that the rainwater harvesting system has been effective and efficient during the past four years of occupation where the tank dried only once. Moreover, the maintenance is carried out only for the motor pump. In order to calculate the actual volume of harvesting, it is essential to indicate the required time for the large underground tank to be filled with capacity of 208,175 liters. The Developer stated that it can be filled up within period of three raining days. Officially, the frequency of rainy days in Kuala Lumpur is once every three days [13]. Sequentially, the actual volume of harvested rainwater has been calculated as 208,175 liters per nine days. Statistically, the annualized volume of actual collected rainwater is 8,442,537.12 liters, which saves RM5,487.64 annually. Hence, the actual monthly harvesting is $703,544.76$ liters that saves RM457,304.09 monthly. Accordingly, the daily collected water is calculated as 23,130.23 liters which is less than the estimated amount of collected rainwater.

\section{Water Efficiency Assessment}

Water efficiency has been achieved for outdoor purposes demands of the common area of Mesra Terrace Development where water consumption has been reduced. Specifically, water efficiency can be measured by comparing the amount of collected water to the amount of consumed water for outdoor irrigation, walkway and cars cleaning demands. There are two water resources that deliver water to the common area namely the municipal water supply grid, and rainwater harvesting system. Besides, there are three outlet 
points delivering water from municipal water supply grid to the garden and the clubhouse. Monthly water bills of the three of these outlets were conducted for six months to find the average of monthly water consumption which is equal to 348,600 liters. However, statistically, the actual water consumption is lower than predicted owing to the limited intention by occupants to wash their cars inside the Development as the Developer stated.

The rain water harvested system provides $66.8 \%$ water efficiency for outdoor usage, as TABLE $\mathbf{3}$ indicates. Water efficiency is calculated as the volume of harvested rainwater to the volume of total water consumption via the communal landscape.

TABLE 3. Water saving of outdoor demands

\begin{tabular}{|c|c|c|c|}
\hline Water & $\begin{array}{c}\text { Monthly } \\
\text { water usage }\end{array}$ & $\begin{array}{c}\text { Cost } \\
(\mathrm{RM})\end{array}$ & $\begin{array}{c}\text { Water } \\
\text { saving }\end{array}$ \\
\hline Mains water & $348,600 \mathrm{l}$ & 226,590 & \\
\cline { 1 - 3 } Harvested rainwater & $703,544.76 \mathrm{~L}$ & $457,304.09$ & \multirow{2}{*}{$66.8 \%$} \\
\hline Total Sewerage & $1,052,144.76$ & $683,894.09$ & \\
\hline
\end{tabular}

\section{Green Cost Premium and Lifecycle Savings of the Implemented Green Technologies}

Green premium cost refers to the incurred additional cost required in adding green technologies and sustainable features in buildings. This additional cost is usually estimated during design phase. It is recovered by savings and returns which obtained during efficient and effective performance of the green features and technologies [14] [15].

The ratio of green cost investment is about $4.3 \%$ investing. The green premium cost of each integrated green features and technology in Mesra terrace Development which were conducted with the assistance of the Developer during the indepth interview.

Life-cycle saving (LCS) of the green technology refers to the financial benefits gained from the efficient performance of the sustainable features within its lifetime duration, as the following equation:

Life-cycle saving $(\mathrm{RM})=$ (annual energy saving $(\mathrm{RM})$ * estimated lifetime of the green technology (year)) - (green premium cost + Life-cycle cost of maintenance) , and:

Life-cycle cost of maintenance $(\mathrm{RM})=$ (green premium cost $* 15 \%) *$ lifetime of the green technology (year)

During occupancy phase of a green home life span, revenue returns are obtained from operating the implemented green technologies [16]. Therefore, these revenue returns are known as operational saving. In the long term, green premium cost and maintenance cost of the implemented green technology are recovered by these revenue returns [17] [18], as the following equation:

Payback period $($ year $)=$ green premium cost $(\mathrm{RM}) /$ Life-cycle saving (RM)

Regarding the built underground storage tank of the rainwater harvesting system, its lifetime is counted along with the houses life span which is estimated about 30 years. Hence, calculations of life-cycle saving involve green premium cost, maintenance cost, and operational saving of rainwater harvesting system within its expected lifetime. The life-cycle saving of the integrated rainwater harvesting system in Mesra Terrace Development are calculated, as presented in TABLE 4.

TABLE 4. Life-cycle saving of the integrated green technologies in Mesra Terrace Development and their payback

\begin{tabular}{|c|c|c|c|c|c|}
\hline $\begin{array}{c}\text { Annual } \\
\text { saving } \\
\text { cost } \\
\text { (RM) }\end{array}$ & $\begin{array}{c}\text { Lifetime } \\
\text { (year) }\end{array}$ & $\begin{array}{c}\text { Operation } \\
\text { al saving } \\
\text { (RM) }\end{array}$ & $\begin{array}{c}\text { Maintena } \\
\text { nce cost } \\
\text { (RM) }\end{array}$ & $\begin{array}{c}\text { Life-cycle } \\
\text { saving } \\
(\mathrm{RM})\end{array}$ & $\begin{array}{c}\text { Payback } \\
\text { period } \\
\text { (year) }\end{array}$ \\
\hline $5,487.64$ & 30 & $164,629.4$ & $40,373.7$ & $-144,902.5$ & $\begin{array}{c}\text { Along its } \\
\text { lifetime }\end{array}$ \\
\hline
\end{tabular}

\section{CONCLUSIONS}

Malaysia is dedicated to global environmental concerns, raising ecological awareness among developers and general public as they has contributive part in driving environmental movement in which they realize their roles in supplementing sustainable development. In general, post occupancy performance as approach of analysis shows the involving of economical, and environmental variables. Rainwater harvesting system meet the water saving target in Malaysia. However, this system must be folded into the cost according to the water storage strategy. The cost of using water butts to collect rainfall much differ from building underground cement tank. The developer must combine the costs in such a way that it is affordable to the market sector. Taken to the extreme, the contribution of this research involves several issues of importance concerning driving the affordability of green development in domestic sector in Malaysia that facilitates accustomed sustaining healthy lifestyle of the community. A certain approach of evaluation addressing residential green applications under the tropical climate of Malaysia has to be developed to formulate practical guidelines of domestic and industrial green technologies implementations in order to achieve optimum performance and life-cycle savings associated.

To these ends, the contributory components and linkages of performance of implemented technologies were conclusively exemplified as a guideline, as illustrated in "Fig. 6". Hereupon, it has been established that ecological awareness should be integrated as sustainable strategy to orient occupants' behaviour towards green practices and patterns ensuring efficiency and savings of the implemented technology in homes. 


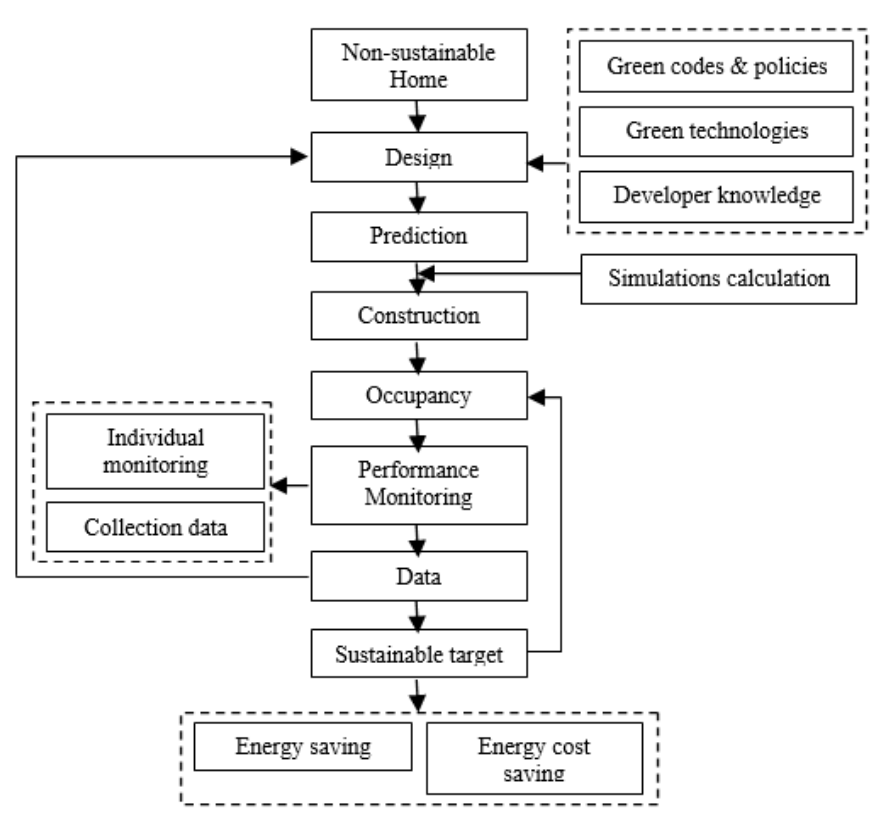

Fig. 6. Approach of evaluating performance of implemented technology in homes after occupancy

\section{ACKNOWLEDGMENT}

We would like to thank the Developer of Mesra Terrace, Msr.Rosmari M. L. Tan, for her favor in collecting the required data upon the local case study.

\section{REFERENCES}

[1] Kaposztasova, D., Vranayovaa, Z., Purcz, P. (2014) Rainwater Harvesting, Risk Assessment and Utilization in Kosice-City, Slovakia. 16th Conference on Water Distribution System Analysis, WDSA 2014. Procedia Engineering 89 ( 2014 ) 1500 - 1506

[2] Friedman, Avi (2007). Sustainable residential development: Planning and design for green neighborhoods. Mc Graw Hill

[3] Campisano, A., Liberto, D., Modic, C., Reitano, S. (2014) Potential for Peak Flow Reduction by Rainwater Harvesting Tanks. 16th Conference on Water Distribution System Analysis, WDSA 2014. Procedia Engineering 89 ( 2014 ) 1507 - 1514

[4] Sehgal, Jitender Dev (2006). A guide to rainwater harvesting in Malaysia. Rotary club of Johor Bahru,, Johor, Malaysia.
[5] Gomez, Y. \& Teixeira, L. (2017) Residential rainwater harvesting: Effects of incentive policies and water consumption over economic feasibility. Resources, Conservation and Recycling. Volume 127, December 2017, Pages 56-67

[6] Lee, Kh., Mokhtar, M., Hanafiah, M., Halim, A., Badusah, J. (2016) Rainwater harvesting as an alternative water resource in Malaysia: potential, policies and development. Journal of Cleaner Production. Volume 126, 10 July 2016, Pages 218-222

[7] Underwood, Lynn (2010). The green home: A decision making guide for owners and builders: Delmar Cengage Learning.USA.

[8] Rovers, Ronald (2008). Sustainable housing projects: implementing a conceptual approach. Amsterdam, Techne press.

[9] Communities and Local Government (2010). The code for sustainable homes: Case studies,Volume2. Communities and local government publications, London.

[10] Lazarus, Nicole (2009). BedZED: Toolkit Part II A practical guide to producing affordable carbon neutral developments. BioRegional solutions for sustainability.

[11] Hodge, J. (2009). BedZED seven years on The impact of the UK's best known eco-village and its residents. BioRegional development group, BedZED centre, 24 Helios Road, Wallington, Surrey SM6 7BZ, UK.

[12] Kassim, P. S. J., Ali, M., Abakr, Y. A., Haron, H. A., \& Tan, R. M. L. (2008). Sustainable consciousness with commercial viability. Paper presented at Conference on sustainable building SB08 Melbourne, CSIRO- Commonwealth scientific and industrial research organization, Australia.

[13] Camerlengo, A. L. \& Somchit, N. (2000). Monthly and annual rainfall variability in peninsular Malaysia. Universiti Putra Malaysia Press, Pertanika 1. Sci. \& Techno 8(1), 73 - 83.

[14] Hoque , S. (2010). Net zero energy homes: An evaluation of two homes in the Northeastern United States. Journal of Green Building (5)2,79-90.

[15] Phillips, Y. (2012). Landlords versus tenants: Information asymmetry and mismatched preferences for home energy efficiency. Energy Policy 45, 112-121.

[16] Langdon, D. (2012). Enterprise green communities criteria: Incremental cost, measurable savings update. Enterprise green communities. Retrieved June 11, 2012.

[17] Shafiei, M. W. M., Samari, M., Ghodrati, N. (2013). Strategic approach to green home development in Malaysia- the perspective of potential green home buyers. Life Science Journal 10(1), 3213- 3224.

[18] Zaid, N. S. M. (2013). Measuring electricity-elated GHG emissions and he affordability in Malaysia low-cost housing: A case study of low-cost housing projects in Kuala Lumpur. 